\title{
Holger Auel \\ Egg size and reproductive adaptations among Arctic deep-sea copepods (Calanoida, Paraeuchaeta)
}

Received: 13 October 2003 / Revised: 14 March 2004 / Accepted: 29 March 2004 / Published online: 20 May 2004 (C) Springer-Verlag and AWI 2004

\begin{abstract}
Reproductive strategies of the four congeneric and sympatric calanoid copepods Paraeuchaeta glacialis, $P$. norvegica, $P$. barbata, and $P$. polaris were studied in the Arctic Greenland Sea. Females of all species produce egg sacs and carry their brood attached to the genital opening until the offspring hatch. However, egg size and lipid content as well as clutch size and the fraction of females carrying egg masses show characteristic differences among the four species. P. glacialis and P. norvegica produce large numbers (37 to more than 50 ) of relatively small eggs, whereas $P$. barbata and $P$. polaris rely on small numbers (10 to 19 and 4 to 6 , respectively) of large eggs with a high energy content. There is no correlation between female body size and egg size or clutch size, respectively. Females of the smallest species, $P$. polaris, produce relatively large eggs and show the highest energetic investment per egg. In contrast, energetic investment per clutch is highest in $P$. glacialis. Reproductive adaptations appear to be strongly related to the depth range inhabited by the respective species. In the central Greenland Sea $P$. glacialis and $P$. norvegica occur in the epipelagial and upper mesopelagial, whereas the other two species inhabit lower mesopelagic to bathypelagic depths. Thus, egg size increases with depth of occurrence, whereas clutch size is inversely correlated with depth. This observation leads to the hypothesis that the evolution of large eggs in deep-sea copepods may enable hatchlings to rely on a lecithotrophic development and thus represents a successful adaptation to cope with the limited food supply at great depths, whereas high offspring numbers in epipelagic species compensate for higher predation risks in the euphotic zone.
\end{abstract}

Communicated by H.-D. Franke

H. Auel (๘)

Marine Zoology (FB 2),

University of Bremen,

P.O. Box 330 440, 28334 Bremen, Germany

e-mail: hauel@uni-bremen.de

Tel.: +49-421-2189566

Fax: +49-421-2182285
Keywords Egg brooding - Energetic investment - Lipid content . Euchaetidae $\cdot$ Aetideidae

\section{Introduction}

Calanoid copepods of the genus Paraeuchaeta represent dominant components of zooplankton communities throughout the world ocean, especially in deep oceanic waters (Park 1994; Fleddum et al. 2001). They are carnivorous, actively preying on other zooplankton organisms, and may even affect the recruitment success of commercially important fish stocks (Bailey and Yen 1983; Yen 1987).

Due to their large body size Paraeuchaeta belongs to the ten most important taxa with respect to biomass in the Greenland Sea (Richter 1994). In the adjacent Arctic Basin P. glacialis is one of the five most frequently encountered calanoids (Grainger 1989), comprising 1 to $6 \%$ of the total biomass of all Arctic copepods (Kosobokova 1982).

A characteristic feature of copepod communities in different parts of the world ocean is the sympatric cooccurrence of several to many Paraeuchaeta species in any given area. In the Rockall Trough, north-east Atlantic, for instance, 14 Paraeuchaeta species with $P$. norvegica as the most abundant representative were reported by Mauchline (1992, 1994a). Similarly, 14 congeneric species occurred around South Georgia in the Southern Ocean, where $P$. antarctica and $P$. biloba were the most dominant forms (Ward and Wood 1988). For the Arctic Ocean the four congeners $P$. glacialis, $P$. norvegica, $P$. barbata, and $P$. polaris have been described (Grainger 1989). Co-occurring congeners are often restricted to specific depth ranges, thus vertically partitioning the water column, as has been demonstrated for the 2500-m-deep Rockall Trough (Mauchline 1992, 1994a, 1995). This vertical partitioning of the water column by closely related species with overlapping distribution ranges makes species of the genus Paraeuchaeta 
extremely useful targets for studies on depth-related adaptations to the pelagic deep-sea environment.

The vertical distribution and reproductive behaviour of sympatric Paraeuchaeta populations have been intensively studied in the Rockall Trough, north-east Atlantic (Mauchline 1994a, 1994b, 1995). Paraeuchaeta species, as well as some aetideids, differ from the dominant herbivorous epipelagic Calanus species in their spawning behaviour. Whereas Calanus are free spawning, Paraeuchaeta females produce egg sacs and carry their brood attached to the genital opening until the offspring hatch. In the Rockall Trough, the egg diameter and the generation times of sympatric Paraeuchaeta species were positively correlated with increasing depth of occurrence (Mauchline 1995). Based on these observations, the author identified the depth-dependent decrease in water temperature as the determining factor for reproductive adaptations in deep-sea copepods. In addition, Mauchline suggested that the increasing environmental stability at greater depth may reduce individual variations in body measures and buffer the amplitudes of seasonal changes in the life cycles.

Here I present data on reproductive adaptations of the four Arctic Paraeuchaeta species. In addition, some information on the two aetideid species Chiridius obtusifrons and Aetideopsis minor, which also produce egg sacs, is included. The different reproductive strategies of the epi- and bathypelagic Paraeuchaeta congeners are outlined and discussed with respect to depth-associated changes in environmental parameters. I challenge the hypothesis that the depth-dependent decrease in water temperature represents the major factor determining egg size in deep-sea copepods.

\section{Methods}

The vertical distribution of Arctic deep-sea copepods of the families Euchaetidae and Aetideidae was studied in the central Greenland Sea between 28 May and 2 June 1997 during the expedition ARK XIII/1 of the German polar research vessel "Polarstern" (Spindler et al. 1998). Stratified samples were collected at six stations along a transect on $75^{\circ} \mathrm{N}$ between 7 and $14^{\circ} \mathrm{W}$ (Fig. 1). Sampling covered the depth intervals of 0-50-100-200-500$1,000-1,500-2,000 \mathrm{~m}$ or down to the sea floor. The mouth opening of the Multinet measured $0.25 \mathrm{~m}^{2}$ and mesh size was $150 \mu \mathrm{m}$. Additional material for biochemical analyses was obtained from Bongo net hauls (mesh 100 to $330 \mu \mathrm{m}$ ) collected during the same expedition.

All samples were transferred to a cooling container immediately after capture for further processing. All euchaetid and aetideid copepods were sorted, staged, and measured alive under in situ conditions $\left(0\right.$ to $\left.4^{\circ} \mathrm{C}\right)$, before deep freezing at $-80^{\circ} \mathrm{C}$. In addition, the fraction of females carrying egg sacs, mean number of eggs per clutch, and egg diameter were determined. To measure the individual dry mass of copepods and egg clutches, frozen individuals were dried by lyophilisation for $48 \mathrm{~h}$ and subsequently weighed on a Sartorius micro-balance with a precision of $10 \mu \mathrm{g}$. In the case of the egg clutches, samples from neighbouring stations had to be pooled.

Total lipids were extracted and determined gravimetrically essentially according to Folch et al. (1957) and Bligh and Dyer (1959). Copepod and egg samples were transferred into an organic solvent (dichloromethan:methanol, 2:1 by volume) and ho-

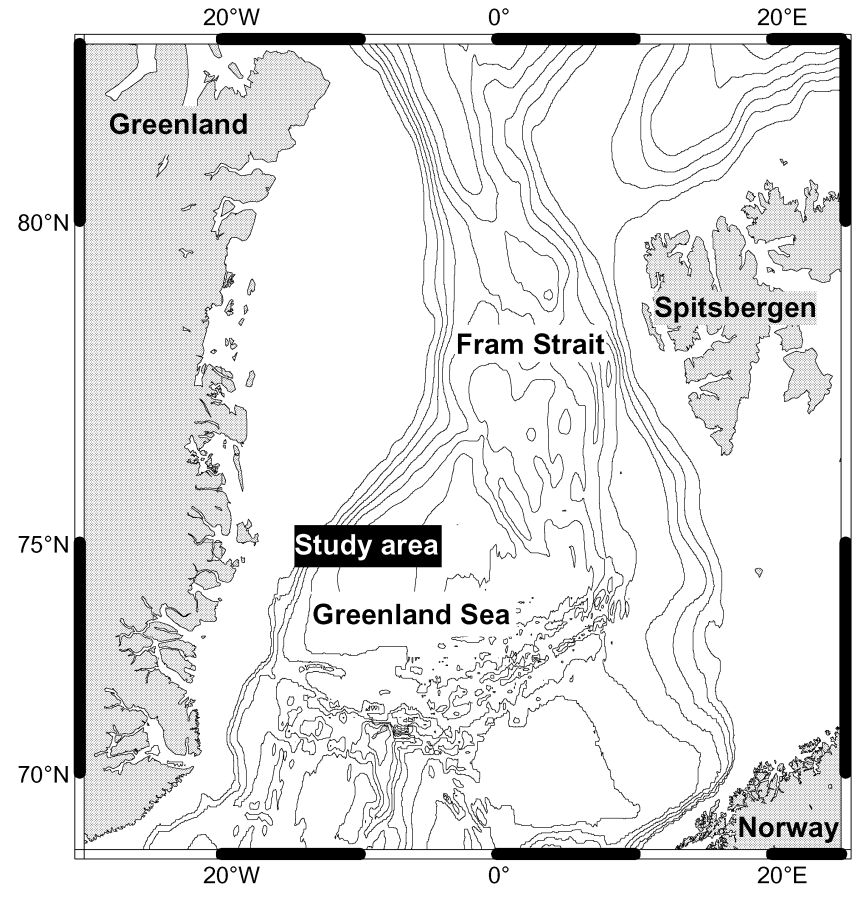

Fig. 1 Map of study area

mogenised mechanically and by ultrasonic methods. To clean the extract, a $\mathrm{KCl}$ solution was added as hydrophilic phase. The mixture was shaken, centrifuged, and the organic phase removed. After the evaporation of the solvent under a nitrogen atmosphere, the extracted lipids were weighed on a micro-balance (Hagen 2000). This method efficiently removes 95 to $99 \%$ of all lipids from the samples (Christie 1982). If necessary, samples from neighbouring stations were pooled to obtain a sufficient quantity of lipids.

Based on dry mass and lipid content, a two-compartment model was designed to calculate the caloric content of eggs and to estimate the energetic investment of females in egg production. Assuming a caloric value of $39.6 \mathrm{~kJ} \mathrm{~g}^{-1}$ for lipids and that the remaining fraction of dry mass consisted of proteins and carbohydrates with an average caloric value of $20.5 \mathrm{~kJ} \mathrm{~g}^{-1}$ (Sommer 1998), the total energy content of eggs, clutches, and females can be determined according to

\section{$E=\left(L \times 39.6 \mathrm{Jmg}^{-1}+(1-L) \times 20.5 \mathrm{Jmg}^{-1}\right) \times M$}

where $E$ is energy content (joules), $L$ is lipid content as fraction of total dry mass, and $M$ is total dry mass (milligrams).

Ratios between the energy content of eggs and clutches, respectively, and that of females were calculated to assess the energetic investment of females in reproduction. This approach was necessary since the total lipid content of the eggs was considerably higher than that of the females, so that a simple ratio between dry mass values would have been inappropriate.

\section{Results}

\section{Vertical distribution}

In the central Greenland Sea the four congeners Paraeuchaeta glacialis, $P$. norvegica, $P$. barbata, and $P$. polaris occur sympatrically. The analysis of the stratified hauls, however, revealed distinct depth ranges for the different species (Fig. 2). Adult P. glacialis and P. nor- 


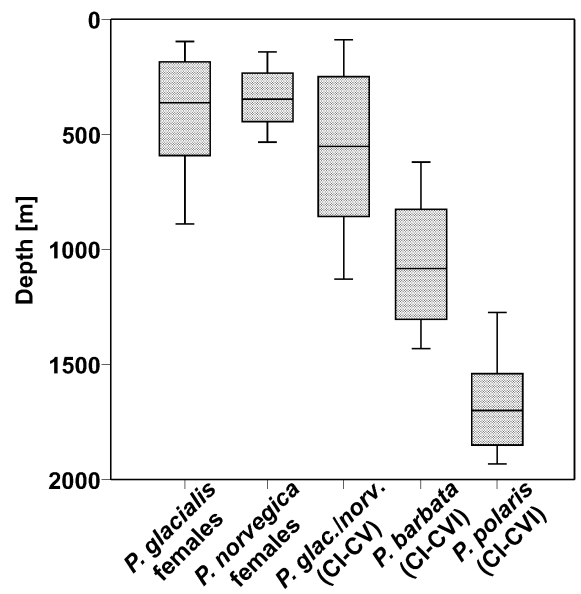

Fig. 2 Vertical distribution of Paraeuchaeta glacialis, P. norvegica, $P$. barbata, and P. polaris in the central Greenland Sea. Boxes include $50 \%$ of the population; whiskers encompass the 10th to the 90th percentile. The horizontal bar indicates the median depth. CI to $C V I$ Copepodite stages CI to CVI

vegica mainly inhabit the upper $500 \mathrm{~m}$ with younger copepodids occurring down to $1,000 \mathrm{~m}$ depth. In contrast, $P$. barbata is most abundant between 900 and $1,300 \mathrm{~m}$ depth, and $P$. polaris is restricted to a bathypelagic range below $1,500 \mathrm{~m}$. Thus, a vertical partitioning was apparent among the four congeners.

\section{Reproductive adaptations}

Females of all Paraeuchaeta species as well as the aetideid Chiridius obtusifrons were caught with egg masses attached to their genital openings. Under laboratory conditions during the present study, it was observed that eggs of another aetideid copepod, Aetideopsis minor, also stuck to each other and stayed attached to the female's genital somite, apparently similar to the egg sacs produced by $C$. obtusifrons. Unlike $C$. obtusifrons, however, egg masses of A. minor were fragile and easily detached. Therefore, it is uncertain whether A. minor produces attached egg masses only under sheltered laboratory conditions or whether this is also the case in the field. Rough sampling procedures may destroy the fragile egg masses or detach them from the females, so that they are not usually found in mesozooplankton net samples.

For the more rigid egg sacs of Paraeuchaeta species and $C$. obtusifrons various parameters were measured to evaluate the energetic investment of females in egg production and to elucidate different reproductive strategies (Table 1). The fraction of females carrying egg sacs strongly differed among the four Paraeuchaeta species. Among the bathypelagic $P$. barbata and $P$. polaris half to two-thirds of all females had egg sacs attached to their genital somite. In contrast, only $11.5 \%$ of $P$. glacialis and $17.0 \%$ of $P$. norvegica females carried eggs. For $C$. obtusifrons the fraction was even lower $(8.4 \%)$. The extremely low value of $2.7 \%$ for A. minor is probably a

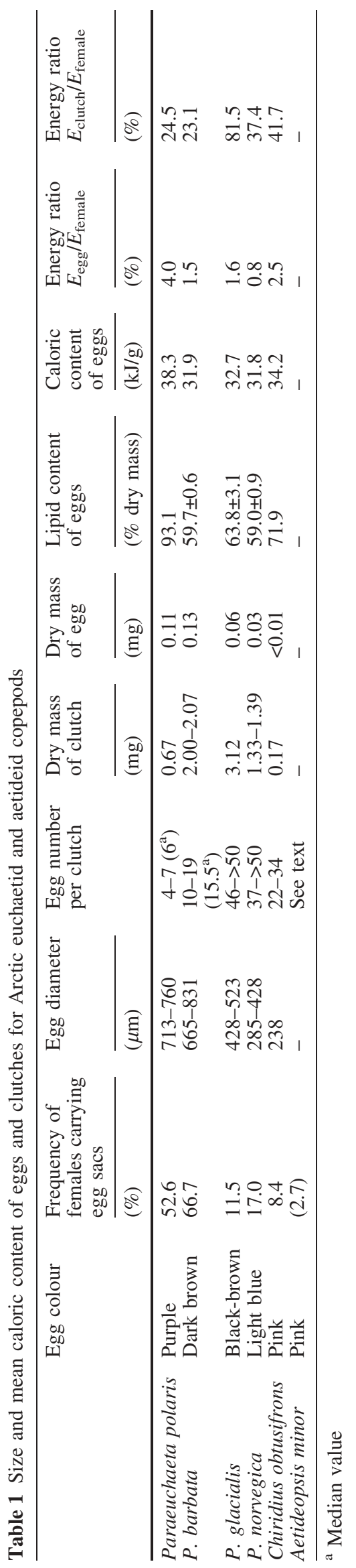


Fig. 3 Egg and clutch sizes of $P$. polaris, $P$. barbata, $P$. glacialis, and $P$. norvegica

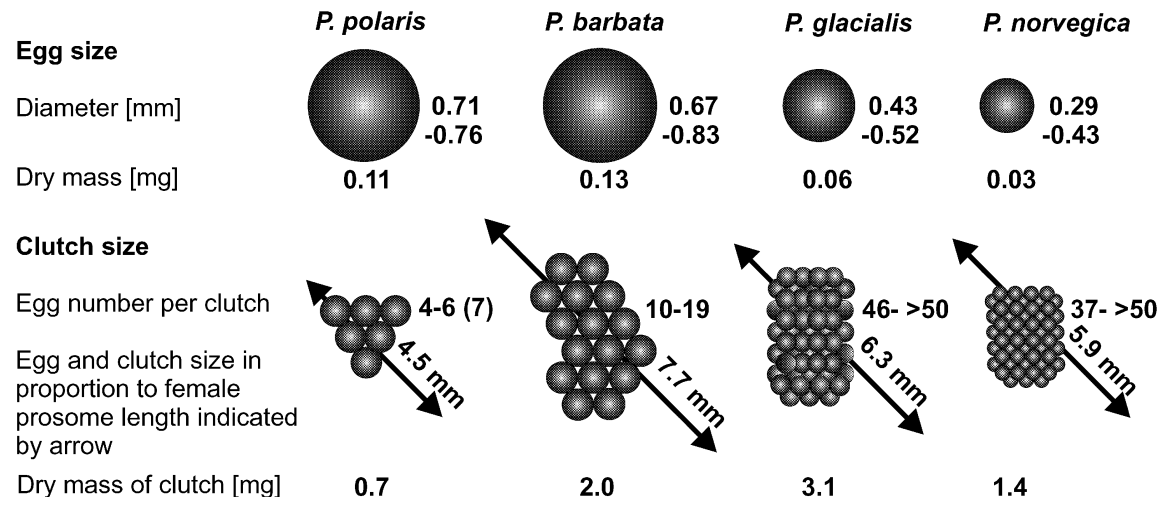

Apparently, the number of eggs per clutch was negatively correlated with depth of occurrence. Thus, egg numbers decreased from a range of 40 to more than 50 per clutch in epipelagic $P$. glacialis and $P$. norvegica to less than 20 and 6, respectively, in the deep-sea congeners $P$. barbata and $P$. polaris (Fig. 3). In relation to their body mass, $P$. glacialis females produced the largest clutches, exceeding $3 \mathrm{mg}$ dry mass, which is equivalent to more than two-thirds of the female's dry mass or $81.5 \%$ of the female's energy content (Fig. 4c, Table 1).

Energetic investment per egg, however, was highest in $P$. polaris. Large size and high lipid content required $4 \%$ of the female's energy per egg. In contrast, other congeners invested only 0.8 to $1.6 \%$ of their energy in a single egg (Fig. 4b, Table 1).

These results reveal pronounced differences in the reproductive strategies of epi- to mesopelagic and bathypelagic congeners. The deep-sea species $P$. barbata and, in particular, $P$. polaris produce low numbers of large eggs with relatively high energy content, whereas epi- to mesopelagic $P$. glacialis and $P$. norvegica produce high numbers of smaller eggs, resulting in a substantially higher energetic investment for the whole clutch.

Based on these data, it can be assumed that bathypelagic $P$. polaris and $P$. barbata, which invest less than a quarter of their body energy per clutch, can rely primarily on lipid reserves to fuel egg production. In contrast, high investments of $81.5 \%$ of body energy per clutch in $P$. glacialis are only possible if sufficient food is available.

\section{Discussion}

The present study reveals that four species of the genus Paraeuchaeta co-occur in the central Greenland Sea. The same species have been reported also for the adjacent Arctic Ocean (Grainger 1989). In spite of the absence of physical barriers, each species inhabits a distinct depth range, so that a characteristic multi-layered vertical distribution pattern emerges for the four congeners in the Greenland Sea. The reasons for this vertical partitioning are not fully understood. However, vertical changes in water temperature are unlikely to be of any relevance, since the Greenland Sea is characterised by low and lipid contents of more than $90 \%$, resulting in an elevated caloric content of $38.3 \mathrm{~kJ} \mathrm{~g}^{-1}$ (Fig. 4a, Table 1). 
rather stable temperature profiles between -2 and $+2{ }^{\circ} \mathrm{C}$ throughout the water column.

The reproductive behaviour and adaptations of dominant epipelagic Calanus species have been intensively studied in the Arctic (e.g. Conover 1967, 1988; Conover and Huntley 1991; Hirche 1989, 1996, 1997; Hirche and Bohrer 1987). In contrast, many elements of the life history of meso- and bathypelagic species remain only incompletely described (Ohman and Townsend 1998). In the case of deep-sea copepods the determination of basic parameters such as egg size, clutch size, and reproductive investment by females often suffers from inappropriate collection techniques because the long periods of time required to retrieve animals from depth, together with abrasion in nets, often cause specimens to be damaged and egg masses to be lost (Ohman and Townsend 1998). Studies of deep-sea organisms in polar regions with stable and cold water temperatures throughout the water column can at least partly mitigate these problems, since the samples do not need to pass a warm surface layer that would usually stress or even kill sensitive deep-sea organisms adapted to cold and stable ambient temperatures.

In spite of the widespread distribution of Paraeuchaeta species in oceanic and polar waters, most previous studies on their life-cycle strategies and reproductive behaviour have been confined to boreal coastal areas, for example, Loch Etive in Scotland (Nemoto et al. 1976), Korsfjorden in western Norway (Båmsted 1975; Bakke 1977), and the Norwegian Sea (Fleddum et al. 2001). Only limited data are available for polar regions and these mainly focus on Antarctic and sub-Antarctic populations (Ward and Robins 1987; Øresland 1995; Alonzo et al. 2000a, 2000b). All Paraeuchaeta species produce egg sacs and carry their offspring until hatching. Thus, they strongly deviate in their reproductive strategies from the other large but predominantly herbivorous polar copepod genera Calanus and Calanoides, of which all are free spawners. The brooding behaviour in Paraeuchaeta is combined with a substantial reduction of egg numbers in comparison to free-spawning species. Based on these observations, Paraeuchaeta seems to exhibit a tendency towards K strategies (Hagen 1999). Due to their carnivorous feeding habit, the timing of reproduction does not appear to be strictly linked to the productive season. Reproductive activities of $P$. antarctica, for instance, culminate in late summer and in winter (Ward and Robins 1987; Øresland 1995; Alonzo et al. 2000a, 2000b). Especially bathypelagic species seem to reproduce year-round (Mauchline 1994a, 1995, 1998).

The development of ovisacs and a brooding behaviour is obviously a beneficial strategy for planktonic copepods, since it substantially increases egg survival. The mortalities of brooded eggs of marine copepods seem to be at least one order of magnitude lower than those of broadcast eggs (Kiørboe and Sabatini 1994; Logerwell and Ohman 1999). This adaptation has been independently developed by various groups of copepods including small cyclopoids as well as large calanoids such as Paraeuchaeta. However, the actual benefits of the brooding behaviour appear to be strongly dependent on the body size of the copepod concerned. The size distribution of egg-brooding copepod species is bimodal, comprising a number of small-bodied and large-bodied species, with only few intermediate-sized species between 10 and $100 \mu \mathrm{g} \mathrm{C}$ body mass (Ohman and Townsend 1998).

It can be assumed that the brooding behaviour is inevitably combined with some negative trade offs. The large egg masses may result in the higher energetic cost of locomotion and reduced swimming speeds due to the increased drag. Reduced swimming speeds probably lead to a lower escape performance and a higher risk of predation. This would increase the mortality rate of brooding females in comparison to free-spawning ones. Additionally, in the case of predatory copepods reduced mobility may also negatively affect the success rate during prey capture. Moreover, both effects would even be enhanced by the high visibility and conspicuousness of the often brightly coloured egg masses that on the one hand could attract visual predators and on the other hand deter potential prey (Logerwell and Ohman 1999, and references therein). The effects of these negative trade offs of the brooding behaviour may to a certain extent depend on the body size of the copepod species concerned and on the depth range inhabited, with strongest consequences for intermediate-sized copepods occurring in the euphotic zone, where visual predators, such as fish and hyperiid amphipods, are abundant. Such a relationship would explain the interrupted size distribution of egg-brooding copepod species described by Ohman and Townsend (1998).

In the case of the very large and deeper-living Paraeuchaeta species the advantages of the brooding behaviour apparently exceed its negative trade offs. Deep-sea copepods are presumably less affected by enhanced predation risks since encounters with predators are generally less frequent in the scarcely inhabited deep sea than in epipelagic strata. Moreover, most meso- and bathypelagic predators, like Paraeuchaeta itself, rely on tactile or rheotactic prey perception in the dark deep-sea environment. Therefore, optically conspicuous egg masses may not significantly enhance predation risk. In predation trials with three-spined sticklebacks the mortality of large copepods such as Paraeuchaeta was not significantly affected by the presence or absence of ovisacs (Logerwell and Ohman 1999). The authors therefore concluded that the importance of egg masses in determining female mortality should perhaps not be considered an a priori condition. In the case of Paraeuchaeta, the presence of ovisacs may not be a severe hindrance during prey capture, either. The species is a rheotactic predator, applying a "float and wait" strategy until prey comes in reach. Then prey organisms are caught by a fast attack of the enlarged maxillipeds. Thus, a reduced swimming speed of brooding females may not significantly affect the success rate of prey capture.

The benefits of a brooding versus a free-spawning behaviour for the survival rate of the offspring are obvious. After demonstrating that the negative trade offs of 
this adaptation appear to be less problematic for large, deep-sea copepods, it is interesting that even within the general concept of this adaptation different Paraeuchaeta species have developed distinct reproductive strategies, apparently linked to their depth of occurrence. Compared to the epi- to mesopelagic congeners $P$. glacialis and $P$. norvegica, the bathypelagic forms $P$. barbata and $P$. polaris are characterised by larger egg size, combined with a reduction of egg numbers per ovisac. $P$. polaris females invested $4 \%$ of their body energy per egg, in comparison to only 0.8 to $1.6 \%$ in other congeners. Mauchline (1995, 1998) tried to explain the positive correlation between egg diameter and depth of occurrence as a consequence of a depth-dependent decrease in ambient temperature. However, the present study revealed that the same trend occurred under arctic conditions with stable temperature profiles throughout the water column.

Therefore, the following hypothesis is proposed to explain depth-dependent changes in egg size. Low numbers of large, energy-rich eggs in bathypelagic species can be interpreted as an adaptation to a food-limited environment. They enable early ontogenetic stages to rely on internal energy reserves for development (lecithotrophic development), making them relatively independent of the adverse feeding conditions at bathypelagic depths. Thus, energy-rich eggs seem to be a successful reproductive strategy for ensuring a higher survival rate of the new generation in the food-limited deep sea. In contrast, epipelagic species produce a large number of relatively small eggs. The offspring probably do not depend on energy reserves, since they can benefit from the abundant food supply within the upper water layer (planktotrophic development). Moreover, the large number of eggs may be necessary to compensate for a higher predation risk in the epipelagic realm. Thus, bathypelagic species rely more on a K strategy to cope with adverse but stable feeding conditions, whereas epipelagic species utilise their more variable environment by following an $\mathrm{r}$ strategy. This hypothesis implies that large eggs of bathypelagic species are more likely to be an adaptation to a depth-dependent decrease in foodavailability than to depth-dependent temperature changes.

This interpretation is supported by several studies showing that in a number of copepod species egg size is negatively correlated with food availability, whereas egg number increases under favourable feeding conditions (Hutchinson 1967; Cooney and Gehrs 1980). More recent investigations on the marine copepod Euterpina acutifrons also revealed a trade off between egg number and egg size (Guisande et al. 1996). At low food concentrations, both in the field and under experimental conditions, females produced fewer but larger eggs, resulting in a faster development of nauplii and an increased reproductive success. Similarly, the mean volume of eggs produced by Calanus helgolandicus was inversely related to both food availability and fecundity (egg production per female and day), with increased numbers of smaller eggs being produced during periods of high food avail- ability (Pond et al. 1996). While these investigations confirmed the usefulness of fewer but larger eggs to cope with food limitations on an intraspecific level, the present study shows that the same strategy is also advantageous on the interspecific level in the evolution of closely related species. Moreover, it has been demonstrated that young copepodids are more vulnerable to starvation than older ones (Burns 1985; Borchers and Hutchings 1986; Tsuda 1994; Calbet and Alcaraz 1997). Thus, an increase in egg size at the expense of offspring number seems to be an advantageous strategy for bathypelagic copepods to maximise reproductive success under the poor food supply in the deep sea.

Acknowledgements I would like to thank the captain and crew of R.V. "Polarstern" for their skilful support during the cruise. I am also grateful to the joint zooplankton working group on board including W. Hagen, H.-J. Hirche, I. Werner, M. Graeve, C. Albers, B. Obermüller, and B. Strohscher. Prof. M. Spindler and my former colleagues at the Institute for Polar Ecology in Kiel provided a friendly and inspiring atmosphere during the laboratory work.

\section{References}

Alonzo F, Mayzaud P, Razouls S (2000a) Egg production, population structure and biochemical composition of the subantarctic copepod Paraeuchaeta antarctica in the Kerguelen Archipelago. Mar Ecol Prog Ser 205:207-217

Alonzo F, Mayzaud P, Razouls S (2000b) Egg-production dynamics, biochemical composition and hatching success of the subantarctic copepod Paraeuchaeta antarctica: laboratory studies. Mar Ecol Prog Ser 205:219-227

Bailey KM, Yen J (1983) Predation by a carnivorous marine copepod, Euchaeta elongata (Esterly), on eggs and larvae of the Pacific hake, Merluccius productus. J Plankton Res 5:71-82

Bakke JLW (1977) Ecological studies on the deep-water pelagic community of Korsfjorden, western Norway. Population dynamics of Euchaeta norvegica (Crustacea, Copepoda) from 1971 to 1974 . Sarsia 63:49-55

Båmsted U (1975) Studies on the deep-water pelagic community of Korsfjorden, western Norway. Ecological aspects of individual variations in weight and protein and lipid content of Euchaeta norvegica (Copepoda). Sarsia 59:31-46

Bligh EG, Dyer WJ (1959) A rapid method of total lipid extraction and purification. Can J Biochem Physiol 37:911-917

Borchers P, Hutchings L (1986) Starvation tolerance, development time and egg production of Calanoides carinatus in the southern Benguela Current. J Plankton Res 8:917-925

Burns CW (1985) The effects of starvation on naupliar development and survivorship of three species of Boeckella (Copepoda: Calanoida). Arch Hydrobiol Beih 21:297-309

Calbet A, Alcaraz M (1997) Growth and survival rates of early developmental stages of Acartia grani (Copepoda: Calanoida) in relation to food concentration and fluctuations in food supply. Mar Ecol Prog Ser 147:181-186

Christie WW (1982) Lipid analysis. Pergamon Press, Oxford

Conover RJ (1967) Reproductive cycle, early development, and fecundity in laboratory populations of the copepod Calanus hyperboreus. Crustaceana 13:61-72

Conover RJ (1988) Comparative life histories in the genera Calanus and Neocalanus in high latitudes of the northern hemisphere. Hydrobiologia 167/168:127-142

Conover RJ, Huntley M (1991) Copepods in ice-covered seasdistribution, adaptations, growth patterns and life cycle strategies in polar seas. J Mar Syst 2:1-42 
Cooney JD, Gehrs CW (1980) The relationship between egg size and naupliar size in the calanoid copepod Diaptomus clavipes Schacht. Limnol Oceanogr 25:549-552

Fleddum A, Kaartvedt S, Ellertsen B (2001) Distribution and feeding of the carnivorous copepod Paraeuchaeta norvegica in habitats of shallow prey assemblages and midnight sun. Mar Biol 139:719-726

Folch J, Lees M, Sloane-Stanley GH (1957) A simple method for the isolation and purification of total lipids from animal tissues. J Biol Chem 226:497-509

Grainger EH (1989) Vertical distribution of zooplankton in the central Arctic Ocean. In: Rey L, Alexander V (eds) Proceedings of the 6th conference of the Comité Arctique International 1985. Brill, Leiden, pp 48-60

Guisande C, Sanchez J, Maneiro I, Miranda A (1996) Trade-off between offspring number and offspring size in the marine copepod Euterpina acutifrons at different food concentrations. Mar Ecol Prog Ser 143:37-44

Hagen W (1999) Reproductive strategies and energetic adaptations of polar zooplankton. Invertebr Reprod Dev 36:25-34

Hagen W (2000) Lipids. In: Harris RP, Wiebe PH, Lenz J, Skjoldal HR, Huntley M (eds) ICES zooplankton methodology manual. Academic Press, San Diego, Calif., pp 113-119

Hirche H-J (1989) Egg production of the Arctic copepod Calanus glacialis: laboratory experiments. Mar Biol 103:311-318

Hirche H-J (1996) The reproductive biology of the marine copepod, Calanus finmarchicus-a review. Ophelia 44:111-128

Hirche H-J (1997) Life cycle of the copepod Calanus hyperboreus in the Greenland Sea. Mar Biol 128:607-618

Hirche H-J, Bohrer RN (1987) Reproduction of the Arctic copepod Calanus glacialis in Fram Strait. Mar Biol 94:11-17

Hutchinson GE (1967) A treatise on limnology II. Introduction to lake biology and the limnoplankton. Wiley, New York

Kiørboe T, Sabatini M (1994) Reproductive and life cycle strategies in egg-carrying cyclopoid and free-spawning calanoid copepods. J Plankton Res 16:1353-1366

Kosobokova KN (1982) Composition and distribution of the biomass of zooplankton in the central Arctic Basin. Oceanology 22:744-750

Logerwell EA, Ohman MD (1999) Egg-brooding, body size and predation risk in planktonic marine copepods. Oecologia $121: 426-431$

Mauchline J (1992) Restriction of body size spectra within species of deep-sea plankton. Mar Ecol Prog Ser 90:1-8

Mauchline J (1994a) Seasonal variation in some population parameters of Euchaeta species (Copepoda: Calanoida). Mar Biol $120: 561-570$
Mauchline J (1994b) Spermatophore transfer in Euchaeta species in a $2000 \mathrm{~m}$ water column. Hydrobiologia 293:309-316

Mauchline J (1995) Bathymetric adaptations of life history patterns of congeneric species (Euchaeta: Calanoida) in a $2000 \mathrm{~m}$ water column. ICES J Mar Sci 52:511-516

Mauchline J (1998) The biology of calanoid copepods. (Advances in marine biology, vol 33). Academic Press, San Diego, Calif.

Nemoto T, Mauchline J, Kamada K (1976) Brood size and chemical composition of Pareuchaeta norvegica (Crustacea: Copepoda) in Loch Etive, Scotland. Mar Biol 36:151-157

Ohman MD, Townsend AW (1998) Egg strings in Euchirella pseudopulchra (Aetideidae) and comments on constraints on egg brooding in planktonic marine copepods. J Mar Syst 15:6169

Øresland V (1995) Winter population structure and feeding of the chaetognath Eukrohnia hamata and the copepod Euchaeta antarctica in Gerlache Strait, Antarctic Peninsula. Mar Ecol Prog Ser 119:77-86

Park T (1994) Geographic distribution of the bathypelagic genus Paraeuchaeta (Copepoda, Calanoida). Hydrobiologia 292/ 293:317-332

Pond D, Harris R, Head R, Harbour D (1996) Environmental and nutritional factors determining seasonal variability in the fecundity and egg viability of Calanus helgolandicus in coastal waters off Plymouth, UK. Mar Ecol Prog Ser 143:45-63

Richter C (1994) Regional and seasonal variability in the vertical distribution of mesozooplankton in the Greenland Sea. Ber Polarforsch 154:1-87

Sommer U (1998) Biologische Meereskunde. Springer, Berlin Heidelberg New York

Spindler M, Hagen W, Stübing D (1998) Scientific cruise report of the Arctic expedition ARK-XIII/1 of RV "Polarstern" in 1997. Ber Polarforsch 296:1-65

Tsuda A (1994) Starvation tolerance of planktonic marine copepod Pseudocalanus newmanni Frost. J Exp Biol Ecol 181:81-89

Ward P, Robins DB (1987) The reproductive biology of Euchaeta antarctica Giesbrecht (Copepods: Calanoida) at South Georgia. J Exp Mar Biol Ecol 108:127-145

Ward P, Wood AG (1988) The distribution of the Euchaetidae (Copepoda: Calanoida) around South Georgia. Polar Biol 9:4552

Yen J (1987) Predation by a carnivorous marine copepod, Euchaeta norvegica Boeck, on eggs and larvae of the North Atlantic cod Gadus morhua L. J Exp Mar Biol Ecol 112:283-296 